\title{
Szorstkość lnu i zapach wełny. Wykonywanie ściegu za ściegiem jako forma dialogu z naturą
}

Wykonywanie ściegów to czynność towarzysząca ludzkości od tysięcy lat. Wytwarzanie dzianin znane było już we wczesnej epoce brązu (Sagona, 2018: 283)1. Pierwotnie dzierganie, haftowanie i szycie należały do czynności związanych z wykonywaniem dzianin i tkanin użytkowych. Zgodnie z tradycją tkanie i szycie przez lata stanowity elementy codziennej krzątaniny kobiet odpowiedzialnych za gospodarstwo domowe i rodzinę (Leslie, 2007: XI; Parker, 2010: 6; Haveri, 2013: 2). Dzisiejsze praktyki rękodzielnicze uległy znacznej przemianie, która wynika ze zmiany sposobu ludzkiego życia. Użyteczność przestała być cechą podstawową rękodzieła tekstylnego (Kępa, 2017: 154). Obecnie dłonie wykonujące ściegi tylko z pozoru powtarzają ruchy o archaicznej strukturze, związanej z dawnymi kodami społecznymi, nieaktualnymi preferencjami, koniecznościami i zwyczajami.

W prezentowanym artykule podejmowaniu rękodzielniczej aktywności przyglądam się ze szczególnej perspektywy. Wykonywanie tekstyliów traktuję bowiem jako dialogiczny proces tworzenia wiedzy, kreowania rzeczywistości oraz komunikowania się z przeszłością za sprawą pracy rąk tych, którzy przetwarzają materiały organiczne na łonie natury. W przedstawiony tekst wplatam ponadto wątki autoetnograficzne ${ }^{2}$, pośrednio realizując $w$ ten sposób postulat dotyczący bezpośredniego dotykania rzeczy, które chcemy zrozumieć - prowadzenia badań poprzez uczestnictwo, rozumiane jako praktyczna praca z materiałami (Ingold, 2018: 7). Istotną częścią artykułu jest zapis moich doświadczeń, które towarzyszyły mi w procesie odtwarzania ściegów zetlałej Inianej serwety. Zastosowanie autoetnografii pozwoliło mi na objęcie analizą praktyki należącej do zdarzeń codziennych i niepozornych, wartych uwagi ze względu na ich osadzenie w konkretnym miejscu i czasie, w ściśle określonym kontekście społeczno-kulturowym.

1 Najstarszą formą wytwarzania tekstyliów za pomocą nici i igły było pętelkowanie (looping) - ścieg igłowy określany także mianem ściegu koptyjskiego (Coptic stitch), znanego również pod nazwą Tarim stitch. Metoda ta polegała na stopniowym wykonywaniu ściegu igłą z przewleczoną przezeń nicią (Turnau, 1979: 11; Graves Jr., 2008; Vajanto, 2014: 22; Claßen-Büttner, 2015: 34).

2 Autoetnografia to metoda postępowania badawczego, której podstawę stanowi żywe i namacalne doświadczenie (Holman Jones, 2005: 764). Osobiste przeżycia badacza służą w niej tworzeniu zniuansowanych, złożonych i wyczerpujących opisów kulturowych norm, doświadczeń i praktyk (Adams, Holman Jones, Ellis, 2015: 33). 


\section{Trwanie}

Ziarno - łodyga - przędza - ściegi - obecność i powolne rozpadanie się splecionych włókien. Geneza i koniec, który nie nastąpi.

\section{Istoty ludzkie „pływające w oceanie materiałów”}

Zgodnie z tezą brytyjskiego antropologa Tima Ingolda jako ludzie należymy do istot „pływających w oceanie najróżniejszych materiałów”, uczestnicząc w ich przekształcaniu oraz podlegając oddziaływaniom tego, co nas otacza. Tak postrzegana rzeczywistość ulega nieustannemu wytwarzaniu i transformacji, a nasze z nią relacje stanowią bardziej lub mniej efemeryczne formy zakrzepłego ruchu (Ingold, 2018: 17). Ingold pisze: „ludzie [...] rodzą się i wzrastają w nurcie materiałów i uczestniczą od wewnątrz w ich dalszej transformacji” (Ingold, 2018: 28). Rękodzielniczą pracę z włóknami i przędzą pochodzenia naturalnego postrzegać można zatem przez pryzmat przepływu materii w świecie - przepływu, któremu istoty ludzkie podlegają na równi ze wszystkimi innymi stworzeniami³.

Praca z materią polega na jedynie chwilowym przejęciu kontroli nad jej obiegiem. Gotowy przedmiot - rzecz, niezależnie od tego, czy będzie to wełniany sweter, czy ceglany budynek, składa się bowiem z materiałów, których ruchu zatrzymać się nie da. Materiały, nigdy nieujarzmione całkowicie, nadal będą się mieszać i przekształcać, grożąc zawierającym je rzeczom powolnym rozpadem. Sweter z czasem przetrze się na łokciach, a cegły zaczną kruszyć (Ingold, 2018: 22).

Praktyki wytwarzania to wysiłki istot żywych ustanawiających swoje relacje z otoczeniem. W ujęciu Ingolda nie polegają one na nadawaniu formy (morphe) materii (hyle), ale na wytwarzaniu więzi z otaczającym światem. Kwestionując zakorzeniony w myśli zachodniej hylemorficzny model tworzenia, badacz odwołuje się do filozofii Gilles’a Deleuze’a i Fèlixa Guattariego, wedle których podstawową relacją w świecie istot żywych nie jest związek materii i formy, ale relacja „materiału” i „sit” (Ingold, 2018: 122). Ingoldowi chodzi zatem o to, by wspomniany model zastąpić „ontologią, która przyznaje pierwszeństwo procesom kształtowania, a nie produktom końcowym, oraz przepływom i przekształceniom materiałów, a nie stanom materii" (Ingold, 2018: 123).

Świat konstruowany jest zatem poprzez wytwarzanie połączeń przypominających plątaninę wiązek i szlaków tworzonych przez ludzi, organizmy żywe i przedmioty. Przypomina stale tkany gobelin (tapestry). Jest „polem relacyjnym”

3 Zagadnienie to szerzej omawiam w publikacji Kępa, 2020. 
złożonym nie z połączonych ze sobą punktów (interconnected lines), ale przeplatających się linii (interweaving lines). Tak postrzegany świat nie jest siecią (network), ale tym, co Ingold nazywa siatką (meshwork) (Ingold, 2009: 150-151): „każdy organizm - a nawet każda rzecz - sam(a) w sobie jest splataniem, tkanką węzłów, których pasma składowe - powiązane z innymi pasmami, w innych wiązkach - tworzą siatkę" (Ingold, 2018: 91).

\section{Tworzenie a nieuchronny rozpad}

Dotyk i zapach. Spojrzenie na zetlałe fragmenty. Pragnienie ocalenia i bezradność wobec upływu czasu.

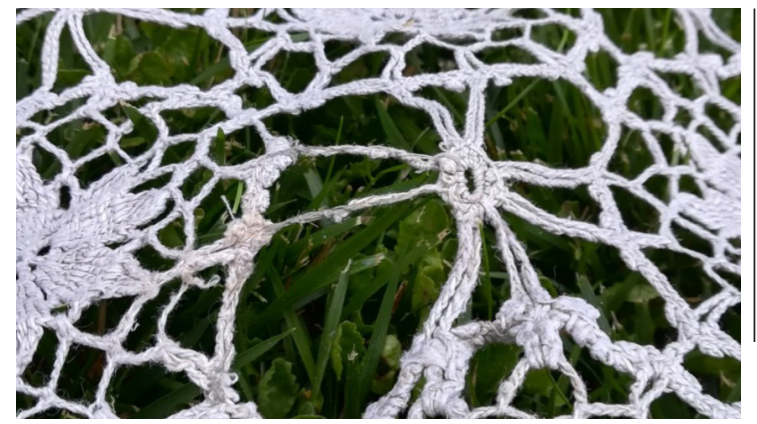

Ilustracja 1

Zetlałe fragmenty Inianej serwety połączone bawełnianą nicią (fot. Ewa Kępa)

Źródło: archiwum autorki.

\section{Ręczne wykonywanie ściegów jako forma percepcji rzeczywistości poprzez jej wytwarzanie}

W ujęciu Ingolda świat jest „otwarty” i nieustannie kreowany w wyniku procesów twórczych i transformacyjnych. Zdaniem antropologa w owym procesie istotną rolę odgrywa człowiek posługujący się swoim ciałem (Ingold, 2018: 18, 128, 148). Znaczeniu ciała w percepcji i doświadczaniu świata wiele uwagi poświęcił bliski Ingoldowi Maurice Merleau-Ponty. Zgodnie z zaproponowaną przez niego koncepcją podmiotu ludzkie „ciało nie jest przedmiotem pozbawionym świadomości, sterowanym przez wyposażony w świadomość umyst, lecz jedynym sposobem bycia w świecie i bycia tego świata świadomym" (Klekot, 2018: 153). W ujęciu Merleau-Ponty'ego człowiek jako podmiot za pomocą ciała wchodzi w relację ze światem i do niego przynależy. Ciałem „realizuje swoją tożsamość”, dzięki ciału poznającemu (corps-connaissant) „wkracza w świat”. Filozof ujmuje to następująco: „moje istnienie jako podmiotowości stanowi jedno z moim istnieniem jako ciałem 
i istnieniem świata" (Merleau-Ponty, 2001: 430). Merleau-Ponty mówi o ucieleśnionej podmiotowości splątanej z cielesnością świata (Murawska, 2008: 129). Ciało w ujęciu autora Fenomenologii percepcji to podmiot aktywnie doznający. Jest ono „zawsze zaangażowane pośród rzeczy, związane z nimi wieloma obiektywnymi stosunkami, każe im wspótistnieć ze sobą i sprawia, że w nich wszystkich bije puls jego własnego trwania" (Merleau-Ponty, 2001: 324). Poprzez ciało człowiek komunikuje się ze światem, a ów bezpośredni kontakt jest źródłem sensu, który ciało „wprowadza do świata”. Ciało ma bowiem zdolność wykraczania ku światu, będąc „ciałem rzeczywistym, będącym elementem przyrody, w którą zostaliśmy rzuceni i która jest obecna jednocześnie w nas i poza nami” (Murawska, 2008: 130). Dzięki niemu możemy zrozumieć świat.

Zainspirowana powyższymi rozważaniami traktuję ręczne wykonywanie ściegów jako jedną z form kreatywnego zaangażowania ludzkiego ciała w konstruowanie świata, jako sposób percepcji rzeczywistości poprzez jej wytwarzanie. W przypadku rękodzieła w procesie tym istotną rolę odgrywają dłonie i opuszki palców - silnie unerwione, niezwykle wrażliwe części ludzkiego ciała, służące do badania fizycznego otoczenia. Ręka tworząca sploty dotyka, odczuwa bodźce, manipuluje materiałami i narzędziami. Praktykowanie rzemiosła tekstylnego, podobnie jak tworzenie ceramiki, rzeźbienie czy malowanie, można zatem określić mianem „myślenia poprzez ręce” albo „poprzez materiał” (thinking through hands, thinking through material) (Mäkelä, 2017).

Akt tworzenia rękodzieła ma wymiar cielesny. Jest „aktem współpracy pomiędzy umysłem, ciałem i materiałem" (collaborative act between mind, body, and material), odbywającym się w określonym środowisku (Aktaş, Mäkelä, 2019: 56). Ręce rękodzielnika, wytrenowane w technice danego rzemiosła, wykonują ruchy kontrolowane przez umyst. Nie są to jednak ruchy mechaniczne, wolne od indywidualnej ekspresji twórcy. Socjolog Richard Sennett mówi wręcz o „intymnym połączeniu ręki z głową" (intimate connection between hand and head), podkreślając, że dobry rzemieślnik prowadzi dialog między konkretnymi praktykami a myśleniem (between concrete practices and thinking) (Sennett, 2008: 9).

Praktyka rzemieślnicza jest zatem „wynikiem negocjacji pomiędzy materiatem a twórcą" (the result of a negotiation between the material and the maker), a powstające artefakty oraz ruchy wykonywane przez kształtujące materię ciało wynikają z tego dialogu (Aktaş, Mäkelä, 2019: 55). Podczas procesu tworzenia materiał aktywnie reaguje na oddziaływanie twórcy. Powstający artefakt jest wobec powyższego wynikiem negocjacji pomiędzy istotami ludzkimi i tym, co nieludzkie (Aktaş, Mäkelä, 2019: 57). I jako taki stanowi element siatki połączeń pomiędzy twórcą i światem, który go otacza. 
Proces ręcznego wytwarzania przedmiotów polega na wydobyciu bądź stłumieniu właściwości obrabianych materiałów. Praca rzemieślnika wiąże się z umiejętnym respektowaniem ich cech, opiera się na wiedzy zdobywanej w wyniku bezpośredniej pracy z materiałem - wiedzy rodzącej się z percepcji zmysłowej i z praktycznego zaangażowania (Ingold, 2018: 30). Rękodzielnicze umiejętności nabywane przez ciało twórcy z czasem przyjmują postać działań wykonywanych w rytmie spostrzegania i dostosowywania się do nowych wyzwań w celu poradzenia sobie z nimi (Sennett, 2008: 9). Mowa tu zatem o odwoływaniu się do wiedzy rąk, uobecnianej przez dotyk i ruch - do wiedzy niewystowionej, niewerbalnej (tacit knowledge) (Groth i wsp., 2014: 1642). Ręczne wykonywanie ściegów to proces jej stałego rozwijania, który dokonuje się także wtedy, gdy dłonie odtwarzają wcześniej rozpisany wzór. Opracowane schematy i wyliczenia nie determinują bowiem praktyki rękodzielnika w każdym szczególe. Określają jedynie zakres, w jakim osoba wykonująca sploty się porusza. Zgodnie z założeniami Ingolda dotyczącymi pracy nie tylko artysty, ale i rzemieślnika, realizowanie projektu nie jest zatem narzucaniem bezwładnej materii wcześniej ustalonych form, ale „interweniowaniem w pola sit i prądy materii, w których formy są wytwarzane” (intervening in the fields of force and currents of material wherein forms are generated) (Ingold, 2010: 92). „Praktycy to wędrowcy, włóczędzy, których umiejętność polega na tym, że potrafią znaleźć słoje przyrostu świata i podążać za nimi, naginając je do swego ewoluującego celu" (Ingold, 2018: 123).

\section{Konstruowanie poprzez odtwarzanie}

Śledzenie rękodzielniczych szlaków wytyczonych przed kilkudziesięciu laty przez dłonie splatające ręcznie uprzędzioną Inianą nić to dążenie do odtworzenia nakreślonych dróg na nowo. To dekodowanie ściegów, liczenie oczek, sporządzanie i korygowanie notatek oraz próby wykonywania ściegu za ściegiem z nici wyprodukowanych maszynowo.

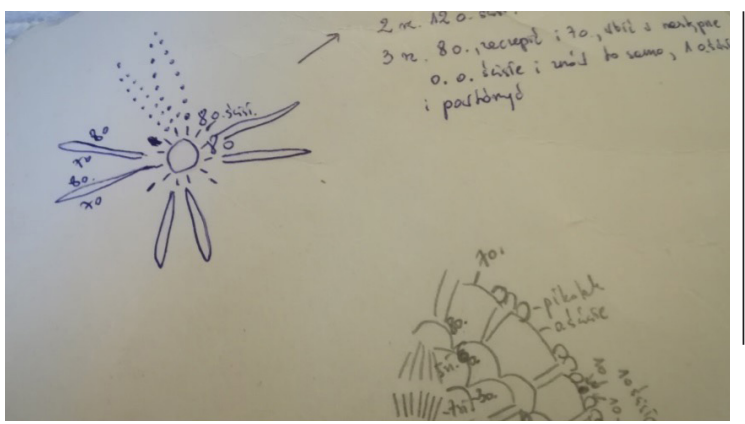

Ilustracja 2

Notatki będące zapisem procesu dekodowania wzoru Inianej serwety sprzed kilkudziesięciu lat (fot. Ewa Kępa) Źródło: archiwum autorki. 


\section{Tworzenie siebie i świata poprzez twórczy akt wykonywania ściegu za ściegiem}

Zajmowanie się robótkami ręcznymi stanowi przejaw „twórczości codziennej”, mającej ogromne znaczenie w rozwoju człowieka (Richards, 2010: 189, 191-193). Twórcze zaangażowanie w świat zaspokaja między innymi potrzebę wywierania wpływu na otaczającą rzeczywistość, komunikowania się i ekspresji siebie. Twórczość codzienna stanowi wyraz indywidualności i samorealizacji jednostki. Efekty twórczych działań nie muszą być niepowtarzalne i wyjątkowe. Istotne jest tu bowiem nie tyle wykonane przez człowieka dzieło, ile przeżycie siebie jako podmiotu kreacji (Modrzejewska-Świgulska, 2009: 148-149; Mendecka, 2010: 7). W wymiarze osobistym twórczość codzienna jest przede wszystkim niezbędna w procesie konstruowania poczucia własnego „ja” (de Certeau, 2008). Jest dialogiem prowadzonym ze światem w celu nawiązania z nim relacji.

Zgodnie z tradycją ręczne wykonywanie dzianin przez lata stanowito przejaw dbałości o gospodarstwo domowe i rodzinę. Jako takie należało do podstawowych obowiązków kobiet. Choć dzierganie, haftowanie czy szycie wielokrotnie stanowito okazję twórczej samorealizacji, na ogół pozostawało jednak przede wszystkim konieczną do wypełnienia powinnością (Parker, 2010; Wolf, 2014: 33). Obecnie tekstylia produkuje się przemysłowo na masową skalę, a ich praco- i czasochłonne ręczne wykonywanie nie należy już do czynności koniecznych ani powszechnych. Rękodzielnicze praktyki kulturowe uległy dziś znacznemu przeobrażeniu, stając się między innymi oryginalnym narzędziem służącym do twórczego „stwarzania siebie” i oddziaływania na otaczający świat (Kenning, 2015: 24).

Barwnym przykładem twórczego zaangażowania w kreowanie otaczającej rzeczywistości jest dziergane graffiti (knitting graffiti) - forma street artu polegająca na umieszczaniu w miejscach publicznych ręcznie wykonanych dzianin i haftów (Kępa, 2017: 241)4. Jej twórczynie i twórcy wydzierganymi elementami okrywają między innymi drzewa, pomniki, ogrodzenia i słupki parkingowe. Ich działalność jest sposobem „estetycznego argumentowania” na rzecz zmiany świata na lepsze. Stanowi praktykę kulturową, która dzierganie ściegu za ściegiem przekształca w serię rękodzielniczych mikropolitycznych gestów. Cele przyświecające twórcom dzierganego graffiti są zróżnicowane. Jedni wykonują oczko za oczkiem z myślą o „ociepleniu” miast i uczynieniu ich bardziej przyjaznymi. Inni buntują się przeciwko konsumpcjonizmowi i życiu w pośpiechu. Zwalniają tempo, tworząc ręcznie rzeczy wyjątkowe i niebanalne. Knitting graffiti bywa przez nich traktowane jako sposób wyrażania alternatywnego punktu widzenia, zwracania uwagi na cenione

4 Knitting graffiti bywa również nazywane yarn bombing (bombardowanie przędzą), yarn storming (szturmowanie włóczką), yarn graffiti (włóczkowe graffiti), guerrilla knitting (partyzanckie dzierganie) oraz urban knitting (miejskie dzierganie). 
wartości i idee. Dzierganie staje się tym samym formą rękodzielniczego aktywizmu (craftivism), aktem oporu wobec kultury konsumpcyjnej oraz sposobem inicjowania i prowadzenia politycznego i społecznego dialogu (Garber, 2013: 60).

Własnoręczne wykonywanie haftów i dzianin, także w formie „craftywizmu”, stanowi jednak przede wszystkim narzędzie służące kreowaniu własnej wersji siebie. Robienie na drutach czy szydełku w wielu przypadkach odgrywa znaczącą rolę w projektowaniu tożsamości indywidualnej, kulturowej i społecznej (Turney, 2004: 278). Tożsamości, o której, w obliczu możliwości oferowanych przez technologie informacyjne, można dziś opowiadać szeroko nie tylko w świecie realnym, ale także na łamach internetu. Dzięki blogom, podcastom i serwisom społecznościowych osoby tworzące rękodzieło tekstylne mają możliwość przynależenia do społeczności obejmującej tysiące, a nawet miliony dziergających ${ }^{5}$, stanowiącej bogate źródło inspiracji i wsparcia. W sieci wiele osób zamieszcza fotografie i filmy o swoich projektach, włóczkach, organizowanych bądź odwiedzonych rękodzielniczych festiwalach oraz technikach wykonywania splotów. Amatorki i amatorzy robótek ręcznych ${ }^{6}$, korzystający z mediów społecznościowych, dumnie prezentujący efekty swojej pracy, często opowiadają przy tym o swoim życiu, rodzinie, przyjaźniach, książkach, filmach czy muzyce. Robótki ręczne dla jednych pozostają relaksującą formą wypoczynku, dialogiem z przeszłością czy sposobem komunikowania się z osobami o podobnej pasji. W przypadku innych z czasem przekształcają się w zajęcie zarobkowe.

Akt wykonywania ściegu za ściegiem jest ponadto rodzajem praktyki zmysłowej, podejmowanej w poszukiwaniu zaspokojenia pragnienia stworzenia przestrzeni dla piękna i kreatywności (Campbell, Dalton, 2019: 29). Twórcza praca z tkaninami niesie ze sobą obietnicę odczuwania radości czerpanej z tworzenia pięknych rzeczy, którą Ann Rippin nazywa „radością ucieleśnioną” (embodied joy) (Rippin, 2020: VIII). W sposób szczególny doświadczyć jej można, sięgając po materiały naturalne i wykonując ścieg za ściegiem na łonie natury.

\section{Dotyk szorstkiego Inu}

Odczuwam przyjemność w dotykaniu szorstkiego Inu. Niezapetniony fragment Inianego płótna i Iniana przędza za każdym razem przyciągają moją uwagę, niosąc ze sobą obietnicę zmysłowego kontaktu z fakturami i kolorami, za pomocą któ-

5 Portal Raverly zrzesza miliony dziergających z całego świata.

6 Pisząc 0 osobach praktykujących robótki ręczne, używam zarówno rodzaju żeńskiego, jak i męskiego oraz męskoosobowego i niemęskoosobowego. Warto jednak podkreślić, że wśród osób zajmujących się rękodziełem tekstylnym nadal dominują kobiety.

0 mężczyznach robiących na drutach pisałam szerzej w tekście Kępa, 2019. 
rych utrwalam ślady odbytych spotkań, spacerów i podróży. Nie przeszkadza mi, gdy wykonywanie ściegów z wykorzystaniem szorstkiej nici pozostawia na moich dtoniach otarcia.

\section{Uobecnianie przeszłości poprzez wykonywanie ściegu za ściegiem „na łonie natury”}

Świadomie lub nieświadomie nasz subiektywny sposób widzenia świata staje się częścią wszystkiego, co robimy. Nie możemy tworzyć rzeczy bez osadzania w nich nas samych (Jaffe, 2014: 1). Jednocześnie wykonywanie ściegu za ściegiem za każdym razem odsyła nas do przeszłości i przyszłości. Korzystanie z technik wykonywania ściegów opracowanych przez minione pokolenia jest formą nawiązywania łączności z tymi, których ruchy odnawiamy przez powtarzanie. Proces tworzenia jest tu równie istotny jak jego końcowy „produkt”, a wybór zastosowanych materiałów oraz repertuar wykorzystanych technik stanowi pole, na którym to, co osobiste, łączy się $z$ tradycją.

W wyjątkowej sytuacji znajdują się ci, którym dane było uczyć się rzemiosła od osób najbliższych. Zdobywanie wiedzy poprzez naśladowanie ruchów dłoni obserwowanych bezpośrednio ustanawia więzi odtwarzane później z każdym powtórzeniem wyuczonych gestów (Giard, 2011: 146; Campbell, Dalton, 2019: 33). Kontakt z autorami i autorkami rękodzielniczych aktów dokonuje się także poprzez wytworzone przez nich artefakty - odziedziczone serwety, narzuty i swetry czy zgromadzone w ramach muzealnych zbiorów dzianiny i hafty. Rękodzieło przywołuje obecność nie tylko bliskich, których już z nami nie ma, ale także osób, których nie mieliśmy szansy spotkać. To obecność, którą - za Dariuszem Czają - nazywam „obecnością zapośredniczoną” (Czaja, 2019: 73).

Zgodnie z tezą Ingolda haftowane obrusy, makatki czy szydełkowe serwety nie są martwymi przedmiotami, ale „rzeczami”. Opisanie ich stanu i własności jest jednoznaczne nie tylko z opowiedzeniem historii ich powstania, ale także:

[...] tego, co przydarzyło i przydarza się rzeczom w czasie, gdy były i są używane, przetwarzane i wystawiane na działanie różnorodnych czynników: pogody, organizmów, ludzi, reakcji chemicznych, innych materiałów (Wala, 2016: 205).

Podjęcie próby ich odtworzenia otwiera kolejne rejony rękodzielniczych doświadczeń.

Wykonywanie rękodzieła jest dynamiczną praktyką kulturową, uwarunkowaną przez wiele czynników - geograficznych, politycznych, materiałowych, społecznych 
i ekonomicznych. Proces odtwarzania wzoru zaczerpniętego z przeszłości podlega oddziaływaniu licznych okoliczności. O przebiegu, charakterze i rezultacie rękodzielniczych działań decydować mogą: dostępność materiałów, pozycja ekonomiczna, cenione wartości czy posiadane umiejętności. Powielenie wzoru stworzonego w przeszłości nie jest zatem niemożliwe. Nasze gesty, także te, które usiłujemy wykonywać w bliskości z naturą, jedynie z nim rezonują (Mann, 2018: 94-95).

Dialog z naturą podejmowany współcześnie przez osoby zajmujące się rękodziełem tekstylnym jest zatem daleki od doświadczeń tych, którzy dziergali w przeszłości. Pierwotnie wykonywanie ściegu za ściegiem oznaczało funkcjonowanie zgodne z cyklami natury - począwszy od zbioru i wysiewu nasion w celu pozyskania włókien roślinnych, umiejętnej hodowli zwierząt, z których otrzymywano wełnę, poprzez pozyskiwanie przędzy, aż po czynność jej splatania, rozpiętą pomiędzy obowiązkiem a radością tworzenia.

Współczesnym rękodzielnikom dzierganie w zgodzie z naturą kojarzy się z przyjemnością kontaktu z organicznymi włóknami, przebywaniem na świeżym powietrzu, w otoczeniu drzew, nad brzegiem morza czy strumienia, a przynajmniej w miejskim parku. Jest postrzegane jako rodzaj relaksującej praktyki, łączącej człowieka z otaczającą przyrodą. Chłodne powiewy morskiej bryzy, a nawet mróz bywają w jej ramach akceptowane. Ten rodzaj dziewiarskiej praktyki jest jednak aktem podejmowanym dobrowolnie, wolnym od konieczności znoszenia niedogodności, jakie towarzyszyły osobom dziergającym na łonie natury w przeszłości. Wówczas wykonywanie dzianin wielokrotnie odbywało się w połączeniu z wywiązywaniem się z codziennych obowiązków. Wspomina o tym Joanna Mann, nawiązująca do tradycji wykonywania szetlandzkich chust. Badaczka zauważa, że praktyka, jaką osobiście podjęła w celu odtworzenia archiwalnego wzoru, polegająca na dzierganiu w wygodnym fotelu, różni się znacznie od zajęcia wykonywanego przez szetlandzkie kobiety, które na drutach robiły nie tylko w czasie wolnym, ale także podczas pracy w polu czy doglądając bydła (Mann, 2018: 97).

Dzierganie wzorów z przeszłości „na łonie natury” to praktyka uobecniania dokonywana nie tylko przez pryzmat upływu czasu, ale także miejsca zamieszkania, doświadczeń osobistych, społeczno-kulturowych relacji i posiadanych umiejętności. Jest to praktyka interpretacyjna podejmowana z wielu różnych powodów. Jedni upatrują w niej ucieczki od zgiełku miejskiego życia, postrzegając spokojne wykonywanie ściegu za ściegiem (slow stitch) jako rytmiczny proces będący źródłem łagodnego i refleksyjnego doświadczenia. Inni traktują ją jako sposób poznawania własnej kultury, powrót do źródeł (Manning, 2004: 2-3, 15; Derry, 2011; Wellesley-Smith, 2015; Pavko-Čuden, 2017: 5). Dzierganie „w zgodzie z naturą" ucieleśnia wartości, wśród których wymienić można między innymi szacunek 
i troskę o planetę, pragnienie prowadzenia zdrowego trybu życia oraz dbałość o lokalne dziedzictwo kulturowe. Nie brakuje też zwolenników dziergania, którzy za jego pomocą prowadzą międzykulturowy dialog.

\section{Pomiędzy przeszłością a teraźniejszością, pomiędzy obowiązkiem a przyjemnością}

Lniany obrus, którego ściegi odtwarzam dziś w słonecznym ogrodzie, został wykonany przed II wojną światową przez młodą dziewczynę wypasającą gęsi na podlaskiej wsi w ramach wykonywania należących do niej powinności. Szydełkowała go z myślą o wzbogaceniu swojego posagu. Naśladując ruchy jej dłoni kilkadziesiąt lat później, dekonstruuję znaczenia w nim zapisane i wplatam je w tkankę powstającego tekstu.

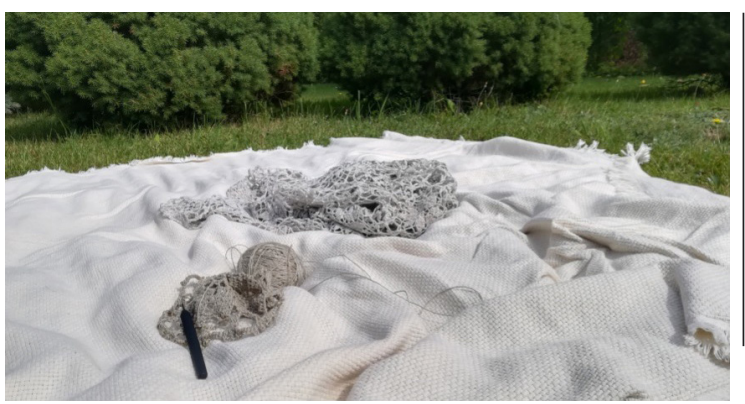

Ilustracja 3

Dzierganie Inianej serwety w ogrodzie

(fot. Ewa Kępa)

Źródło: archiwum autorki.

\section{Dzierganie u podnóża gór i nad brzegiem strumienia zapośredniczone medialnie}

Nieocenioną pomoc i nowe możliwości w zakresie dziergania w łączności z naturą niesie dziś świat wirtualny, stanowiący platformę wymiany doświadczeń ludzi z odległych stron świata. W sieci praktyki dziewiarskie umocowane lokalnie udostępniane są globalnie. Międzykulturowej wymianie doświadczeń i inspiracji wielokrotnie towarzyszy doznanie łączności z naturą w jej „uniwersalnej” formie i poczucie kontaktu z cyklami przyrody dokonującymi się wokół nas niezależnie od tego, z jakiej tradycji czy rejonu świata się wywodzimy.

Media społecznościowe umożliwiają dziergającym obserwowanie bliskich i dalekich twórców prowadzących rękodzielnicze życie w bliskości z naturą. Należą do nich autorzy fanpage'y, blogów i vlogów, często podejmujący się samodzielnego wytwarzania przędzy, opowiadający o trudach i radościach hodowli owiec (Knitography Farm, b.r.) czy farbowania włókien z wykorzystaniem organicznych barwników pochodzących z własnoręcznie uprawianych roślin (Ninja Chickens, b.r.). 
O satysfakcji czerpanej z kontaktu z przyrodą wspominają także ci, którzy koncentrują się na wykonywaniu i projektowaniu dzianin inspirowanych lokalną tradycją kulturową (YouTube, b.r.).

Nie wszyscy obserwatorzy, czytelnicy i subskrybenci wymienionych publikacji internetowych mogą i są gotowi żyć w oddaleniu od świata. Zapewne nie każdy z nich chciałby wstawać o świcie i doglądać owiec bądź pracować w ogrodzie w celu wyhodowania rośliny barwiącej jedwab na niezwykły kolor. Nie każdy miałby odwagę porzucić swoją codzienność na rzecz niepewnego jutra twórcy mieszkającego wysoko w górach lub na wyspie, utrzymującego się głównie z funduszy otrzymywanych w ramach crowdfundingu ${ }^{7}$ oraz ze sprzedaży własnej rękodzielniczej twórczości.

Internet umożliwia dziergającym kontakt z naturą także jako miejsce, w którym można zakupić przędzę. Do włókien wytwarzanych z materiałów organicznych, po które sięgają miłośnicy robótek ręcznych, należą włókna celulozowe pochodzenia roślinnego: bawełna i len, rzadziej juta, konopie czy pokrzywa, oraz włókna białkowe pochodzenia zwierzęcego: wełna, alpaka, jedwab i angora. Wymienione nici, zwykle bardzo drogie, trudno kupić w pobliskiej pasmanterii, gdzie na półkach zazwyczaj dominuje tańsze włókno akrylowe. W sklepach internetowych prowadzonych przez pasjonatów dziergania zdobycie naturalnej, ręcznie uprzędzionej i barwionej włóczki nie stanowi problemu nawet wtedy, gdy od jej wytwórcy dzieli nas ocean. Jedyną trudność, jaką należy pokonać, stanowi zdobycie środków na niezwykle kosztowne zakupy. Przędze z włókien naturalnych, wytwarzane ręcznie ze względu na skomplikowany i czasochłonny proces produkcji należą bowiem do towarów „luksusowych”.

Dzięki globalnej sieci kontaktu z naturą można doświadczyć nie tylko wirtualnie. Internet umożliwia także udział w rękodzielniczych podróżach oferujących dzierganie na łonie przyrody. Wśród nich znajduje się przedsięwzięcie projektantki dzianin Hélène Magnússon, która zaprasza do uczestnictwa w wycieczkach zapoznających z tradycją islandzkiego robienia na drutach (Hélène Magnússon, b.r.). W programie cieszących się niesłabnącym powodzeniem obozów znajdują się między innymi wizyty u lokalnych rzemieślników zajmujących się przędzeniem i farbowaniem wełny. W trakcie zaplanowanych górskich eskapad można także spróbować robienia na drutach w trakcie chodzenia, tak jak robili to islandzcy mężczyźni i kobiety w przeszłości. Internetowe zaproszenie wystosowane przez Magnússon opatrzone jest serią zachwycających zdjęć, oddających piękno lokalnej przyrody i dokumentujących rękodzielnicze przygody uczestników poprzednich edycji dziewiarskich wycieczek. Należy jednak zauważyć, że ci, którzy ruszają przemierzać lodowce i górskie szlaki z drutami w dłoni, motywowani potrzebą powrotu do źródeł

7 Dziewiarze prowadzący kanały w ramach serwisu internetowego YouTube często apelują do swoich widzów o fundusze, na przykład korzystając z platformy Patreon (b.r.). 
dziewiarskich praktyk, nie będą w stanie doświadczyć w pełni realiów życia towarzyszącego osobom dziergającym w przeszłości. Uczestnicy wspomnianych obozów w rzeczywistości odbędą bowiem inspirującą podróż, która po kilku dniach się kończy. Tym, co pozostanie z nimi realnie, będzie dziewiarskie doświadczenie, możliwe do uobecniania w przyszłości poprzez wykonywanie ściegu za ściegiem w nieznanych dotąd kontekstach stale ewoluującego życia społecznego.

\section{Na drodze do nieuchronnego kompromisu}

Po raz pierwszy mam okazję odtworzenia szydełkowej serwety z surowej Inianej przędzy o nierównym splocie, przypominającej nić uprzędzioną ręcznie. Zdobyłam ją w Wilnie, gdzie zatrzymałam się na dwa dni latem ubiegłego roku. Jest zdecydowanie za gruba, by za jej pomocą osiągnąć koronkową lekkość cechującą dzianinę, która trzymam w dłoniach. Wcześniej, rozczarowana efektem podjętego trudu, usiłowałam ją przed kilku laty zrekonstruować z szarych nici bawełnianych.

\section{Zakończenie}

Rękodzieło tekstylne z każdym dniem obejmuje coraz bardziej zróżnicowane praktyki twórcze, odsłaniające swoją wartość w nowych kontekstach kwestionujących jego dotychczasowe definicje (Steed, 2016: 148). Jest środkiem ekspresji oraz rodzajem działalności artystyczno-rzemieślniczej, obejmującej różnorodne dziedziny pracy i wypoczynku (Pavko-Čuden, 2017: 1-2). Zainteresowanie dzierganiem przybiera dziś między innymi formę rękodzielniczego aktywizmu. Bywa także próbą kontynuacji lokalnych zwyczajów.

Ręczne wykonywanie tekstyliów jest zintegrowane z ludzkim życiem. Jego proces i produkty ucieleśniają określone systemy wartości, będąc niewerbalnym wyrazem postaw, emocji i aspiracji jego autorów (Turney, 2004: 279). Haftowanie oraz robienie na drutach i szydełku jest aktem komunikacji, środkiem artystycznej ekspresji oraz formą wypowiedzi społecznej. Zgodnie z antropologią linii Ingolda wykonywanie ściegów stanowi także formę ucieleśnionego sposobu poznawania świata jako jeden ze sposobów uczestniczenia człowieka w „świecie-w-trakcie-tworzenia" (Ingold, 2018: 82). Zajmowanie się rzemiosłem, nadające materii określoną postać, można zatem rozpatrywać w kategoriach procesu poznawczego, odbywającego się w określonym środowisku twórczym, podejmowanego w celu 
ustanowienia swoich relacji z otoczeniem - procesu prowadzącego do konstruowania wiedzy ucieleśnionej (Groth, 2017).

Wykonywanie splotów to sposób negocjowania znaczeń na drodze interakcji pomiędzy myślą ucieleśnioną a środowiskiem materialnym, dialog podejmowany przez dziergających także w obszarze ich relacji z otaczającą przyrodą. W jego ramach dokonuje się między innymi proces twórczego konstruowania i dekonstruowania znaczeń utrwalonych w rękodziele tekstylnym wykonanym z włókien naturalnych, przyjmujący postać uobecniania przeszłości w aktualnych kontekstach społeczno-kulturowych. Ów dialog z naturą bywa zapośredniczany medialnie. Najczęściej przybiera wówczas postać komfortowej „podróży wirtualnej”, w której uczestniczą ludzie wywodzący się z różnych tradycji kulturowych, przenikających się na nieznaną dotąd skalę.

Ekspresja siebie poprzez wytwarzanie rzeczy pięknych leży w ludzkiej naturze, a rzemiosło od zawsze pozostawało istotnym elementem twórczej aktywności człowieka (Jaffe, 2014: 1, 3). Wykonywanie czegoś własnymi rękami to zatem sposób uczestniczenia w świecie. To dialog, interakcja i negocjacje prowadzone pomiędzy osobą a jej otoczeniem. Manipulując określonym materiałem, oddziałujemy na świat. Niezależnie od tego, czy wykonana rzecz jest trwała, czy ulotna, doświadczenie to zmienia też nas samych (Groth, 2017: XI).

Rękodzielnicza praca z włóknami i przędzą pochodzenia naturalnego to przede wszystkim forma relacji człowieka ze światem, w którą wchodzi poprzez ciało. Jest to akt splątania ucieleśnionej podmiotowości z cielesnością świata, polegający na chwilowym przejęciu kontroli nad przepływem materii, któremu istoty ludzkie podlegają na równi ze wszystkimi innymi stworzeniami. W sposób szczególny doświadczyłam tego, dokonując autoetnograficznej redakcji rozpadającej się w dłoniach Inianej serwety, której ściegi utrwaliłam tymczasowo także na kartach prezentowanego tekstu.

\section{Bibliografia}

Adams T.E., Holman Jones S., Ellis C. (2015), Autoethongraphy. Understanding Qualitative Research, New York: Oxford University Press.

Aktaş B., Mäkelä M. (2019), Negotiation between the Maker and Material: Observations on Material Interactions in Felting Studio, ,International Journal of Design", vol. 13(2), s. 55-67.

Campbell L.H., Dalton J. (2019), Researching Contemporary Handwork: Stitching as Renewal, Remembrance, and Revolution, „,Art Education", vol. 4(72), s. 29-35, https://doi.org/10.1080/00043125.2019.1602500

Certeau M. de. (2008), Wynaleźć codzienność. Sztuki działania, przeł. K. Thiel-Jańczuk, Kraków: Wydawnictwo Uniwersytetu Jagiellońskiego.

Claßen-Büttner U. (2015), Nalbinding - What in the World Is That? History and Technique of an Almost Forgotten Handicratf, Norderstedt: Books on Demand.

Czaja D. (2019), Gdzieś dalej, gdzie indziej, Wołowiec: Wydawnictwo Czarne. 
Derry R. (2011), Knitting Together the Strands of My Life: The Secret Pleasure That Frans/in/forms My Work „„Organization Management Journal", no. 8, s. 182-190.

Garber E. (2013), Craft as Activism, ,', The Journal of Social Theory in Art Education", vol. 33, s. 53-66.

Giard L. (2011), Gotować, cz. II, [w:] M. de Certeau, L. Giard, P. Mayol, Wynaleźć codzienność. 2. Mieszkać, gotować, przeł. K. Thiel-Jańczuk, Kraków: Wydawnictwo Uniwersytetu Jagiellońskiego, s. 139-259.

Graves C.M. Jr. (2008), ,'Early Nalbinding: Stitches of the Tarim Mummies" Workshop Given at Kings College 2008, http://www.geocities.ws/ Id_tadhg/Classes/BasicNaalbinding01.pdf (dostęp: 26.06.2020).

Groth C. (2017), Making Sense Through Hands: Design and Craft Practice Analysed as Embodied Cognition, Helsinki: Aalto University, https:// aaltodoc.aalto.fi/bitstream/handle/123456789/24839/isbn9789526071305.pdf?sequence=1\&isAllowed=y (dostęp: 3.07.2020).

Groth C., Mäkelä M., Seitamaa-Hakkarainen P., Kosonen K. (2014), Tactile Augmentation: Reaching for Tacit Knowledge, [w:] K. Niedderer, Y. Lim, E. Stolterman, J. Redström (red.), Proceedings of DRS 2014: Design's Big Debates. Design Research Society Biennial International Conference 16-19 June 2014, Umeå, Sweden, Umeå: Umeå University, s. 1638-1654.

Haveri M. (2013), Urban knitting - the soft side of street art, ,Synnyt/0rygins", no. 2, s. 1-19, https://wiki.aalto.fi/download/attachments/79989026/Minna\%20Haveri.pdf?version=1\&modificationDate=1369646570000\&api=v2 (dostęp: 15.07.2020).

Hélène Magnússon, Icelandic Knitter, https://icelandicknitter.com/category/knitting-tours/all-the-tours (dostęp: 12.08.2020).

Holman Jones S. (2005), Autoethnography: Making the Personal Political, [w:] N.K. Denzin, Y.S. Lincoln (red.), The Sage Handbook of Qualitative Research, Thousand Oaks-London-New Delhi: Sage, s. 763-792.

Ingold T. (2009), Point, Line and Counterpoint: From Environment to Fluid Space, [w:] A. Berthoz, Y. Christen (red.), Neurobiology of 'Umwelt'. How Living Beings Perceive the World. Research and Perspectives in Neurosciences, Berlin-Heidelberg: Springer-Verlag, s. 141-155.

Ingold T. (2010), The Textility of Making ", Cambridge Journal of Economics", vol. 1(34), s. 91-102.

Ingold T. (2018), Splatać otwarty świat. Architektura, antropologia, design, wybór i oprac. E. Klekot, Kraków: Instytut Architektury.

Jaffe N. (2014), Introduction, [w:] C.L. Weida (red.), Crafting Creativity and Creating Craft: Craftivism, Art Education, and Contemporary Craft Culture, Rotterdam-Boston-Taipei: Sense Publishers, s. 1-4.

Kenning G. (2015), 'Fiddling with Threads': Craft-based Textile Activities and Positive Well-being, "Iextile The Journal of Cloth and Culture", vol. 1(13), s. 50-65.

Kępa E. (2017), Dzierganie alternatywne. Knitting graffiti jako twórcza praktyka konstruowania rzeczywistości społecznej, „Kultura Wspótczesna", nr 4(97), s. 151-165.

Kępa E. (2019), Knittting - (Wo)Men's Occupation „„Acta Universitatis Lodziensis. Folia Sociologica”, nr 70, s. 71-83.

Kępa E. (2020), Stąpanie po śladach - metafizyka ekotonu ,', Zzas Kultury", nr 2(205), s. 55-61.

Klekot E. (2018), Linia biegnąca do przodu, [w:] T. Ingold, Splatać otwarty świat. Architektura, antropologia, design, wybór i oprac. E. Klekot, Kraków: Instytut Architektury, s. 145-157.

Knitography Farm, https://www.knitographyfarm.com (dostęp: 20.07.2020).

Leslie C.A. (2007), Needlework Through History: an Encyclopedia, Westport-London: Greenwood Press.

Mann J. (2018), Knitting the Archive: Shetland Lace and Ecologies of Skilled Practice, _Cultural Geographies", vol. 1(25), s. 91-106.

Manning T.J. (2004), Mindful Knitting: Inviting Contemplative Practice to the Craft, Boston-Rutland-Tokyo: Tuttle Publishing.

Mäkelä M. (2017), Matter that Matters: Creativity and Materiality, Department of Design, School of Arts, Design and Architecture, Aalto University, https://www.youtube.com/watch?v=eheQ_tZTBOk (dostęp: 21.06.2020).

Mendecka G. (2010), Wprowadzenie, [w:] G. Mendecka (red.), Oblicza twórczości, Katowice: Wydawnictwo Uniwersytetu Śląskiego, s. 7-12.

Merleau-Ponty M. (2001), Fenomenologia percepcji, tłum. M. Kowalska, J. Migasiński, Warszawa: Fundacja „Aletheia”.

Modrzejewska-Świgulska M. (2009), Badanie twórczości codziennej - perspektywa biograficzna, [w:] K.J. Szmidt (red.), Metody badań pedagogicznych nad twórczościq. Teoria i empiria, Łódź: Wydawnictwo Akademii Humanistyczno-Ekonomicznej.

Murawska M. (2008), Tajemnica żywej cielesności: fenomenologia ciała w ujęciu Mauricéa Merleau-Ponty'ego i Michela Henry'ego , Sztuka i Filozofia", t. 33, s. 127-144.

Ninja Chickens, https://ninjachickens.org (dostęp: 20.07.2020).

Parker R. (2010), Subversive Stitch. Embroidery and the Making of the Feminine, London-New York: I.B. Tauris.

Patreon, https://www.patreon.com (dostęp: 12.08.2020).

Pavko-Čuden A. (2017), Multiple faces of contemporary hand knitting , IOP Conf. Series: Materials Science and Engineering", vol. 19(254), s. 1-6, https://iopscience.iop.org/article/10.1088/1757-899X/254/19/192014/pdf (dostęp: 23.06.2020). 
Richards R. (2010), Everyday Creativity: Process and Way of Life - Four Key Issue, [w:] J.C. Kaufman, R.J. Sternberg (red.), The Cambridge Handbook of Creativity, Cambridge: Cambridge University Press, s. 189-215.

Rippin A. (2020), Foreword, [w:] J. Ward, H. Shortt (red.), Using Arts-based Research Methods: Creative Approaches for Researching, Business, Organisation and Humanities, Cham: Palgrave Macmillan, s. V-IX.

Sagona C. (2018), Two-Needle Knitting and Cross-Knit Looping: Early Bronze Age Pottery Imprints From Anatolia And The Caucasus, ,Oxford Journal of Archaeology", vol. 3(37), s. 283-297.

Sennett R. (2008), The Craftsman, London: Allen Lane.

Steed J. (2016), Hand-knitting in a Digital Era, [w:] N. Nimkulrat, F. Kane, K. Walton (red.), Crafting Textiles in the Digital Age, London: Bloomsbury Publishing, s. 139-152.

Turnau I. (1979), Historia dziewiarstwa europejskiego do początku XIX wieku, Wrocław: Polska Akademia Nauk, Zakład Narodowy im. Ossolińskich.

Turney J. (2004), Here's One I Made Earlier: Making and Living with Home Craft in Contemporary Britain, „Journal of Design History”, vol. 3(17) s. 267-281.

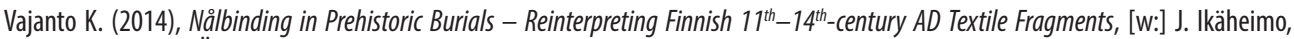
A.-K. Salmi, T. Äikäs (red.), Sounds Like Theory. XII Nordic Theoretical Archaeology Group Meeting in Oulu 25-28.4.2012. „Monographs of the Archaeological Society of Finland", vol. 2, s. 21-33, http://www.sarks.fi/masf/masf_2/SLT_02_Vajanto.pdf (dostęp: 1.07.2020).

Wala K. (2016), Ułożyć świat na nowo. Rekonstrukcja koncepcji Tima Ingolda (cz. I) , Etnografia. Praktyki, Teorie, Doświadczenia”, nr 2, s. 189-209, https://www.ejournals.eu/Etnografia/2017/3-2016/art/12442/ (dostęp: 20.07.2020).

Wellesley-Smith C. (2015), Slow Stitch:Mindful and Contemplative Textile Art, London: Batsford.

Wolf N. (2014), Mit urody, przeł. M. Rogowska-Stangret, Warszawa: Wydawnictwo Czarna Owca.

YouTube, Kammebornia, https://www.youtube.com/channel/UC2BzzBLhQJ-nf8XoDjnZl-A/videos (dostęp: 20.07.2020). 